\title{
Properties Study of Lightweight Partition Board based on Extrusion Molding Process
}

\author{
Xiaoqiao Zhang ${ }^{1, a}$, Xiao Chen ${ }^{1, b}$ and Mingkai Zhou ${ }^{1, c}$ \\ ${ }^{1}$ State Key Laboratory of Silicate Materials for Architectures, Wuhan University of \\ Technology,Wuhan,China \\ a736518974@qq.com, bchenxiao1981@whut.edu.cn, czhoumingkai@163.com
}

Keywords: Lightweight;volume ratio; properties;extrusion molding

Abstract: Lightweight partition board is a newly developed thermal insulation wall material which is mainly composed of lightweight aggregate like ceramisite, glass beads and so on. In this paper ,we prepare it through extrusion molding process which is highly mechanized to save resources and improve productivity. Volume parameters is proposed as a factor affecting performance .The relationship between it and forming performance, compressive strength and density are systematically studied respectively. From the forming performance tests, the increases of power volume and fine particles volume is confirmed to be favorable.The mechanical properties and drainage tests indicate that power volume determines density while fine particles volume determines compressive strength.Glass beads as alternatives of pottery sand reduce compressive strength by $0.8 \mathrm{MPa}$ in average and density by about $20 \%$.

\section{Introduction}

According to the available statistical data , the area of completed housing construction of China is equivalent to that of the sum of the world's developed countries per year ${ }^{[1]}$, which resulted in a great demand in the maintenance structure on housing in construction market. Lightweight partition board, as a new alternative material of maintenance structure, has properties of lightweight, high strength, and excellent thermal insulation.Deng ${ }^{[2]}$ prepared a lightweight PCM wall-material by sol-gel method and the thermal-storing capacity could be greatly improved.Zerihun ${ }^{[3]}$ made numerical experimental and analysis of heat, air, and moisture transfer in a lightweight building wall which verified its excellent properties of thermal insulation.

Extrusion molding process is the direction of advanced material production technology. Materials such as plastic ${ }^{[4]}$, Ni-Fe alloy ${ }^{[5]}$ and polymer materials ${ }^{[6]}$ with excellent properties could be produced by the process which improves productivity and reduces production costs at the same time.Currently, there are not massive extrusion molding technologies used in producing of light weight partition board because has not yet formed a complete material design methods of light partition board based on extrusion molding process.Moreover,the relationship among bulk density, strength and forming performance is difficult to coordinate, which will led to a difficulty of forming the mixing, the uneven surface and crack of the molded article.Promptly, the performance is not controllable.

Therefore, industrial waste-fired ceramisite, pottery sand, and glass beads as the lightweight aggregate, properties of light partition board are studied based on extrusion molding process.It is proposed that volume parameters (powder volume ratio and fine particles volume ratio) is used as a connection between material composition and properties.It is systematically discussed that the relationship between volume parameters of material and molding properties, molding density,and molding strength.

\section{Materials}

In this paper, the raw materials included cement, wet drain off ash and lightweight aggregate.Cement was PO32.5 Portland cement produced by Huaxin Factory in Wuhan, and its general properties are shown in Table 1 . Wet drain off ash was provided by power stations. The density of it was $2.35 \mathrm{~g} / \mathrm{cm}^{3}$ and the moisture content was $18 \%$.Lightweight aggregate included ceramisite,pottery sand, and glass beads. Ceramisite and pottery sand were brown spherical particles, 
while glass beads were white spherical fine particles. The basic properties of lightweight aggregate are listed in Table 2. The particle composition of ceramisite and pottery sand are shown in Fig.1.

Table 1 Detection results of cement technology character

\begin{tabular}{|c|c|c|c|c|c|c|c|c|c|}
\hline \multirow{2}{*}{$\begin{array}{l}\text { Cement } \\
\text { type }\end{array}$} & \multirow{2}{*}{$\begin{array}{c}\text { Fineness } \\
\text { (\%) }\end{array}$} & \multirow{2}{*}{$\begin{array}{c}\text { Water } \\
\text { requirement } \\
\text { of normal } \\
\text { consistency } \\
(\%)\end{array}$} & \multicolumn{2}{|c|}{ Setting time(min) } & \multirow{2}{*}{ Stability } & \multicolumn{2}{|c|}{$\begin{array}{l}\text { Compressive } \\
\text { strength } \\
(\mathrm{MPa})\end{array}$} & \multicolumn{2}{|c|}{$\begin{array}{c}\text { Flexual } \\
\text { strength } \\
(\mathrm{MPa})\end{array}$} \\
\hline & & & $\begin{array}{c}\text { Initial } \\
\text { setting } \\
\text { time(min) }\end{array}$ & $\begin{array}{c}\text { Final } \\
\text { Setting } \\
\text { time(min) }\end{array}$ & & $3 d$ & $28 d$ & $3 d$ & 28d \\
\hline PO32.5 & 7.0 & 27 & 222 & 309 & Qualified & 14.3 & 33.1 & 3.6 & 8.1 \\
\hline
\end{tabular}

Table 2 Results of lightweight aggregate basic properties

\begin{tabular}{ccccc}
\hline $\begin{array}{c}\text { Lightweight } \\
\text { aggregate }\end{array}$ & $\begin{array}{c}\text { Water } \\
\text { absorption(\%) }\end{array}$ & $\begin{array}{c}\text { Bulk } \\
\text { density }\left(\mathrm{kg} / \mathrm{m}^{3}\right)\end{array}$ & $\begin{array}{c}\text { Apparent } \\
\text { density }\left(\mathrm{kg} / \mathrm{m}^{3}\right)\end{array}$ & $\begin{array}{c}\text { Cylinder } \\
\text { compressive } \\
\text { strength(MPa) }\end{array}$ \\
\hline ceramisite & 8.9 & 450.4 & 833.3 & 2.5 \\
pottery sand & 11.5 & 512.4 & 869.6 & 3.5 \\
glass beads & 285 & 180 & 360 & - \\
\hline
\end{tabular}

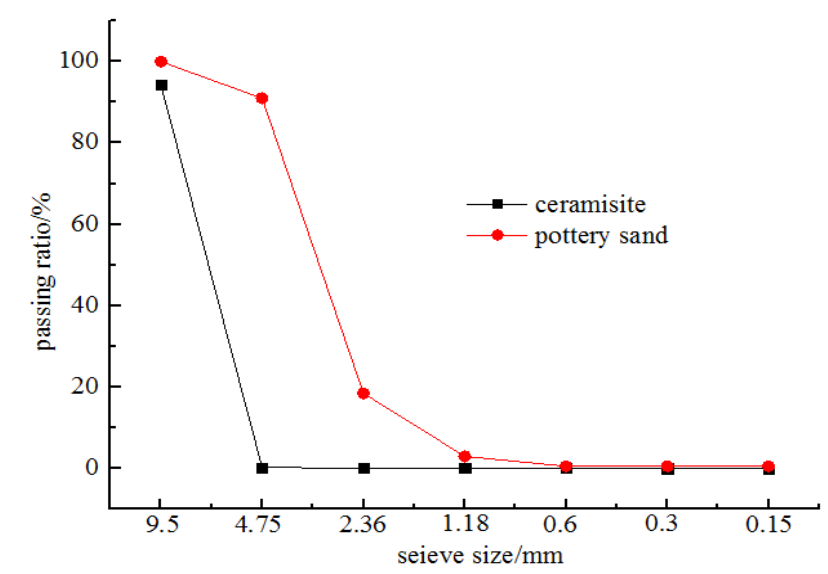

Fig.1 The particle composition of Ceramisite and pottery sand

\section{Experimental}

The properties of lightweight aggregate were tested according to GB/T17431.2-2010. The properties of Cement and Wet drain off ash were examined according to GB/T1346-2001. The lightweight partition board samples were prepared through extrusion molding process, then cut into $100 \mathrm{~mm} \times$ $100 \mathrm{~m} \times 100 \mathrm{~mm}$ size for density and mechanical properties test according to GB/T23451-2009 under dried curing conditions at 7d. Regular watering was needed during curing process.

\section{Results and discussion}

Volume parameters include powder volume ratio and fine particles volume ratio.In this paper, powder volume ratio refers to the sum volume ratio of cement and wet drain off ash.Fine particles include pottery sand and glass beads. The relationship between volume parameters and properties is discussed in cement-ceramisite-pottery sand system and cement- ceramisite-pottery sand-glass beads system, respectively. 
Forming performance refers compactness and smoothness of product. Volume parameters influences it with a effect on powder wrapped rate on aggregate. The relationship between volume parameters and forming performance is discussed here and the results is shown in Table 3.

Table 3 Forming performance of lightweight wall

\begin{tabular}{|c|c|c|c|}
\hline $\begin{array}{l}\text { Powder volume } \\
\text { ratio }\end{array}$ & $\begin{array}{l}\text { Fine particles volume } \\
\text { ratio }\end{array}$ & $\begin{array}{c}\text { Composition of fine } \\
\text { particles }\end{array}$ & $\begin{array}{c}\text { Forming } \\
\text { performance }\end{array}$ \\
\hline 0.2 & & $\begin{array}{c}\text { Ceramic sand } \\
\text { Ceramic sand, glass beads }\end{array}$ & $\begin{array}{l}\text { bad } \\
\text { bad }\end{array}$ \\
\hline 0.22 & & $\begin{array}{c}\text { Ceramic sand } \\
\text { Ceramic sand, glass beads }\end{array}$ & $\begin{array}{l}\text { bad } \\
\text { bad }\end{array}$ \\
\hline 0.24 & 0.8 & $\begin{array}{c}\text { Ceramic sand } \\
\text { Ceramic sand, glass beads }\end{array}$ & $\begin{array}{l}\text { bad } \\
\text { general }\end{array}$ \\
\hline 0.26 & & $\begin{array}{l}\text { Ceramic sand } \\
\text { Ceramic sand, glass beads }\end{array}$ & $\begin{array}{l}\text { general } \\
\text { good }\end{array}$ \\
\hline 0.28 & & $\begin{array}{l}\text { Ceramic sand } \\
\text { Ceramic sand, glass beads }\end{array}$ & $\begin{array}{l}\text { good } \\
\text { good }\end{array}$ \\
\hline 0.26 & 0.6 & $\begin{array}{l}\text { Ceramic sand } \\
\text { Ceramic sand, glass beads }\end{array}$ & $\begin{array}{l}\text { bad } \\
\text { bad }\end{array}$ \\
\hline 0.26 & 0.7 & $\begin{array}{c}\text { Ceramic sand } \\
\text { Ceramic sand, glass beads }\end{array}$ & $\begin{array}{c}\text { general } \\
\text { good }\end{array}$ \\
\hline
\end{tabular}

When fine particles volume ratio is 0.8 , powder volume ratio changes from 0.2 to 0.28 , samples is molded more and more easily, and the smaller size of the fine particles is confirmed as a whole favorable. When powder volume ratio is 0.26 , only fine particle volume greater than 0.7 can ensure smoothness of samples. This phenomenon reflects the characteristics of the extrusion molding process that small particle size materials continue to fill the void to form a dense structure system.

The volume parameters of material determine amount of the raw materials with different density, which will lead to different density of samples.Thus, the relationship between volume parameters and density should be confirmed, the results are shown in Fig.2.

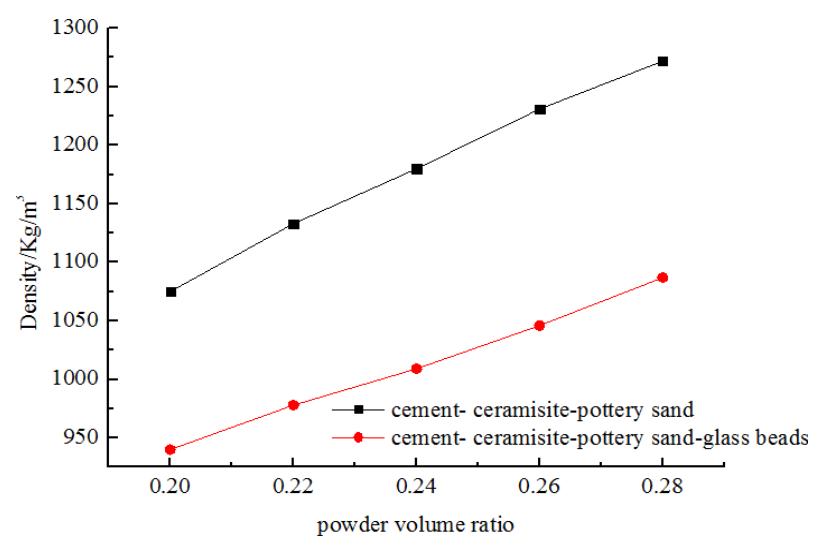

(a)

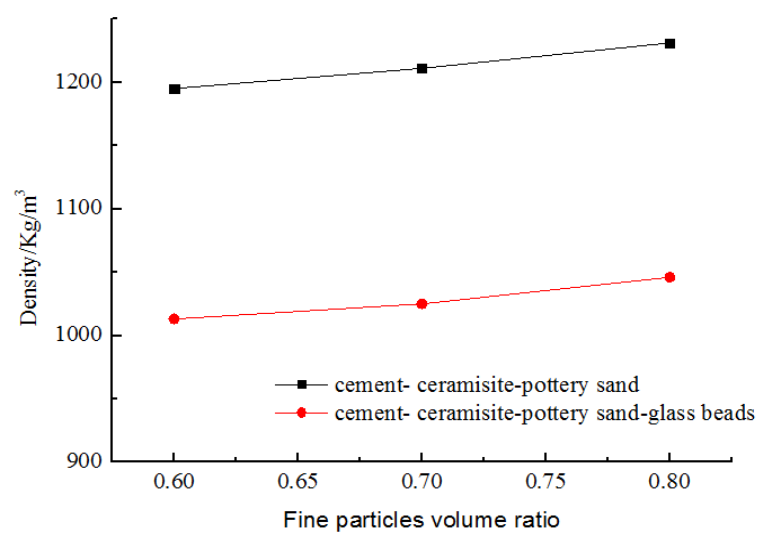

(b)

Fig.2 Influence of (a) powder volume ratio and (b) fine particles volume ratio on density

The powder volume ratio is the dominant factor influencing the density of lightweight wall samples which determines the amount of high-density raw materials.Density increase obviously with increase of its value. With the variation of fine particles volume ratio,density alters a litter because of transformation of skeleton structure type.Low density filler glass beads can significantly reduce density, at this time improving fine particles volume ratio create more quantity of glass beads to lower 
density. The density decreased to $1031 \mathrm{~kg} / \mathrm{m}^{3}$ when the powder volume ratio is 0.26 , fine particles volume ratio is 0.7 , and pottery sand volume ratio is 0.2 .

The relationship between volume parameters and compressive strength is shown in Fig.3.The results indicate both powder volume ratio and fine particles volume ratio have an effect in compressive strength of the lightweight wall samples while fine particles volume ratio with greater effect. The increase of powder volume ratio reduce the water-cement ratio of cement matrix to improve compressive strength, but thus effect is much smaller than the increase of fine particles volume ratio which increases the amount of pottery sand because strength of lightweight aggregate concrete depends mainly on the strength of aggregate. Compared to cement-ceramisite-pottery sand system, adding glass beads cause the average reduce of strength by about $0.8 \mathrm{MPa}$ and above-mentioned discipline is more obvious.

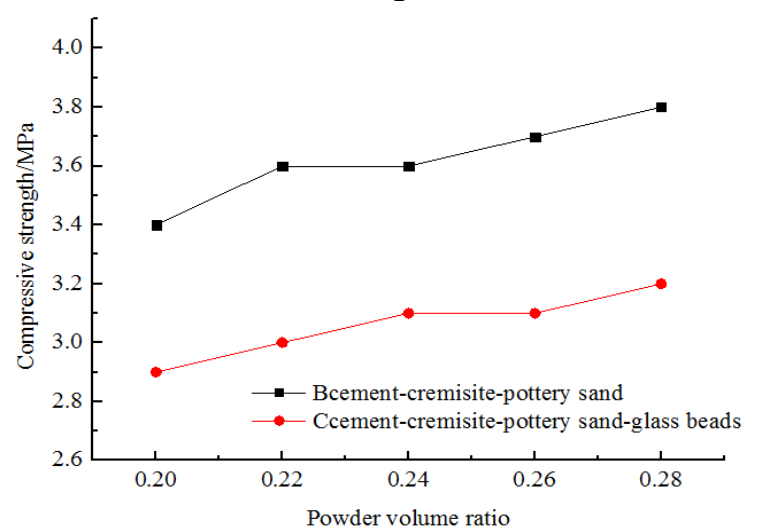

(a)

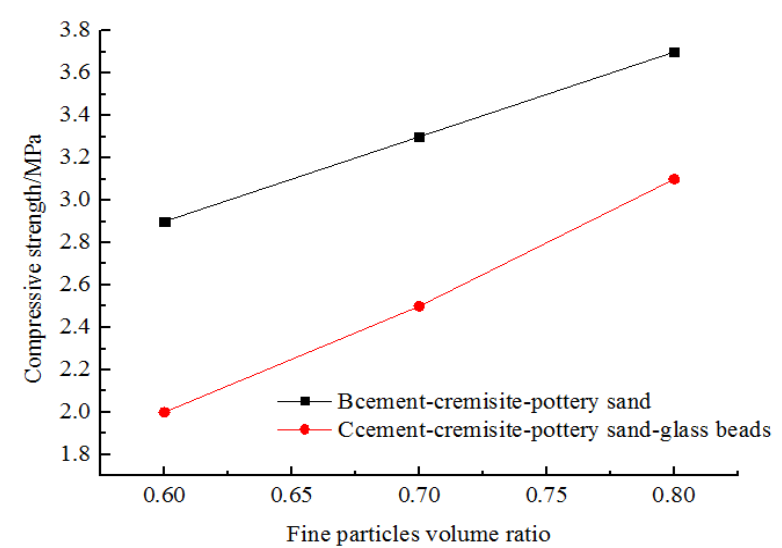

(b)

Fig.3 Influence of (a) powder volume ratio and (b) fine particles volume ratio on compressive strength

\section{Conclusions}

a) Given the characteristics of the extrusion molding process, volume parameters have an effect on forming performance. The thinner the fine particles is, the more easily lightweight wall is formed.

b)The aggregate overall strength is the main factor affecting the strength of lightweight wall, and the discipline is more obvious in cement- ceramisite-pottery sand-glass beads system .Therefore, it is very useful to enhance the strength through increasing fine particle volume rate.

c) Power volume ratio determines the molding density, and changes in the fine particles volume ratio cause transformation of skeleton structure type to influence the molding density a litter .Glass beads replacing part of pottery sand can effectively reduce the density even to $1031 \mathrm{~kg} / \mathrm{m}^{3}$.

\section{References}

[1] Xin Cheng,Xiaozhong Zhao.Overall investigation of affordable residential housing in China[C]. International Conference on Electric Technology and Civil Engineering,2011.

[2] Anzhong Deng.Journal of Building Materials,2008(5):541-544.

[3] Zerihun,T.D\&R.Experimental and numerical analysis of heat, air, and moisture transfer in a lightweight building wall[C].Thermal Performance of the Exterior Envelopes of Whole Buildings - 11th International Conference,2010.

[4] Jicheng Zhou ,Baiyun Huang .Powder Metallurgy Technology,2002(1):13-15.

[5] Wensheng Liu ,Qingshan Cai . International Journal of Refractory Metals and Hard Materials,20 14:233-239.

[6] Changcheng He .Polymeric Materials Science and Engineering,2008(4):155-158. 